\title{
Synergistic and antimicrobial properties of commercial turmeric (Curcuma longa) essential oil against pathogenic bacteria
}

\author{
Propriedades antimicrobianas e sinergísticas de óleo essencial comercial de cúrcuma (Curcuma longa) \\ contra bactérias patogênicas
}

\author{
Sara Albino ANTUNES ${ }^{1}$, Weber da Silva ROBAZZA², Liziane SCHITTLER ${ }^{2}$, Gilmar de Almeida GOMES
}

\begin{abstract}
Several studies have shown the antimicrobial and antioxidant properties of turmeric (Curcuma longa), widely used in food industry as a colorant, among other functions. The aim of this study was to determine the antioxidant and antimicrobial properties of turmeric essential oil against pathogenic bacteria and to study the influence of the addition of ascorbic acid on the prevention of polyphenols oxidation. The commercial turmeric essential oil alone did not show bactericidal activity against the microorganisms studied, Listeria monocytogenes and Salmonella typhimurium, but when combined with ascorbic acid, it showed significant antibacterial activity. The highest antimicrobial activity of turmeric essential oil against Salmonella typhimurium was $15.0 \pm 1.41 \mathrm{~mm}$ at the concentration of $2.30 \mathrm{mg} \cdot \mathrm{mL}^{-1}$ of essential oil and $2.0 \mathrm{mg} \cdot \mathrm{mL}^{-1}$ of ascorbic acid. With regard to Listeria monocytogenes, the largest zone of inhibition $(13.7 \pm 0.58 \mathrm{~mm})$ was obtained at the same concentrations. The essential oil showed antioxidant activity of $\mathrm{EC}_{50}=2094.172 \mu \mathrm{g} \cdot \mathrm{mL}^{-1}$ for the DPPH radical scavenging method and $29 \%$ under the concentration of $1.667 \mathrm{mg} \cdot \mathrm{mL}^{-1}$ for the $\beta$-carotene bleaching method.

Keywords: turmeric commercial essential oil; ascorbic acid; synergism.
\end{abstract}

\section{Resumo}

Vários estudos têm demonstrado as propriedades antimicrobianas e antioxidantes da cúrcuma (Curcuma longa), a qual é amplamente utilizada na indústria de alimentos, entre outras funções, para colorir. O objetivo deste estudo foi determinar as atividades antioxidantes e antimicrobianas do óleo essencial comercial de cúrcuma contra bactérias patogênicas, além de estudar a influência do ácido ascórbico na prevenção da oxidação dos polifenóis. O óleo essencial comercial de cúrcuma não apresentou atividade bactericida contra os micro-organismos estudados, Listeria monocytogenes e Salmonella typhimurium, mas, analisado com o ácido ascórbico, apresentou atividade antibacteriana considerável. A maior atividade antimicrobiana do óleo contra Salmonella typhimurium foi de 15,0 \pm 1,41 mm em uma concentração de 2,30 mg. $\mathrm{mL}^{-1}$ de óleo essencial e 2,0 mg. $\mathrm{mL}^{-1}$ de ácido ascórbico. Para Listeria monocytogenes, o maior halo de inibição (13,7 \pm 0,58 mm) foi encontrado nas mesmas concentrações. O óleo essencial apresentou atividade antioxidante de $\mathrm{EC}_{50}=2094,172 \mu \mathrm{g} \cdot \mathrm{mL}^{-1}$, para o método do radical DPPH•, e de $29 \%$ na concentração de 1,667 mg. $\mathrm{mL}^{-1}$, pelo método de descoloração do sistema $\beta$ - caroteno/ácido linoleico.

Palavras-chave: óleo comercial essencial de cúrcuma; ácido ascórbico; sinergismo.

\section{Introduction}

A recent trend in the food industry is the gradual reduction of chemical additives. In order to accomplish this task, industries have been searching for alternative compounds that control the microbial growth and enhance oxidative stability (SOUZA et al., 2005). Turmeric is an herbaceous evergreen plant in the Zingiberaceae family, which can be found in many locations such as China, India, and some countries of South America (SCARTEZZINI; SPERONI, 2000). Several studies have shown the antioxidant and antimicrobial properties of Turmeric essential oils (NEGI et al., 1999; NEGHETINI, 2006; NAZ et al., 2010). In Brazil, turmeric use has increased mainly due to its coloring property and its ability to improve food odor (CHASSAGNEZ; CORRÊA; MEIRELES, 1997; NEGHETINI, 2006). It is mainly found in ready-to-eat soups, ice-creams, and pasta. The most important compounds responsible for the antioxidant activity of turmeric are phenolic compounds, such as curcuminoid dyes and essential oils (BURKE, 1994; NEGHETINI, 2006). Phenolic compounds exhibit the ability to destroy bacterial cell walls and penetrate into microbial cell affecting its metabolism (MARINO; BERSANI; GIUSEPPE, 2001).

Commercial essential oils have low biological activity due to their extraction and handling processes (HENTZ; SANTIN, 2007; BENELLI, 2010). This behavior is the reason of the growing interest for synergistic compounds that increase the antimicrobial activity of these oils. Accordingly, ascorbic acid is known as the most important natural antioxidant compound present in our daily diet. In addition, it exhibits

${ }^{1}$ Departamento de Engenharia de Alimentos, Universidade Federal de Santa Catarina - UFSC, CP 476, CEP 88040-900, Florianópolis, SC, Brasil

2 Departamento de Engenharia de Alimentos, Centro de Educação Superior do Oeste, Universidade do Estado de Santa Catarina - UDESC, BR 282, Km 573,7, CEP 89870-000, Pinhalzinho, SC, Brasil,e-mail: gilmargomess@yahoo.com.br

${ }^{*}$ Corresponding author 
many physiological and anticarcinogenic activities (LEE et al., 2002; ZAMBUCHINI et al., 2008).

This study aims to estimate the antimicrobial and antioxidant activities of commercial turmeric (Curcuma longa) essential oil and to evaluate the influence of the addition of ascorbic acid on the prevention of polyphenols oxidation.

\section{Materials and methods}

\subsection{Essential oil and physical-chemical analysis}

Commercial turmeric essential oil was purchased from an UK industry. The manufacturer description included: plant from India, oil obtained from vapor distillation of the treated rhizome with $100 \%$ of purity. The oil was yellow in color and exhibited a strong and characteristic odor.

\section{Specific weight $(\gamma)$ and Refractive index analysis}

The weight of a sample of $1 \mathrm{~mL}$ of essential oil was measured at $25{ }^{\circ} \mathrm{C}$ (Analytical balance AY220, SHIMADZU do Brasil Ltda., São Paulo/SP, Brazil). The specific weight was expressed as g. $\mathrm{mL}^{-1}$ of essential oil, and the refractive index analysis was determined using a refractometer (Abbé WYA, 2-WAJ) at $20^{\circ} \mathrm{C}$.

\subsection{Antimicrobial activity}

\section{Disk diffusion method}

The antimicrobial activity of the essential oil against Listeria monocytogenes Scott A and Salmonella typhimurium ATCC 12228 was tested. The bacteria were cultivated in BHI (brain heart infusion) broth at $36^{\circ} \mathrm{C}$ for 24 hours. Bacteria at the concentration of $10^{6} \mathrm{CFU} \cdot \mathrm{mL}^{-1}$ were inoculated in Mueller Hinton Agar (Merck S.A., Brazil). After inoculation, sterile filter paper disks of $6 \mathrm{~mm}$ diameter were placed on the surface of the agar, and solutions at the concentrations of $0.05 ; 0.10$; $0.30 ; 0.50 ; 0.70 ; 0.90 ; 1.00 ; 1.50 ; 2.00 ; 2.30 \mathrm{mg} . \mathrm{mL}^{-1}$ of essential oil were slowly inserted into the disks with a micropipette of $25 \mu \mathrm{L}$. The same amounts of essential oil were tested with the addition of $0.8 \mathrm{mg} \cdot \mathrm{mL}^{-1}$ and $2.0 \mathrm{mg} \cdot \mathrm{mL}^{-1}$ of $\mathrm{L}(+)$ ascorbic acid analytical grade (Dinâmica, Brazil). Pure vitamin C control tests at the above mentioned concentrations were conducted for comparison purposes.

Amoxicillin/clavulanic acid was used as the control sample for Salmonella typhimurium; ampicillin for Listeria monocytogenes; and gentamicin for both microorganisms.
The experiments were performed in triplicate, and the results were expressed in $\mathrm{mm}$ as the arithmetic mean of the inhibition zone values obtained. The data (means) were analyzed by ANOVA and Tukey tests $(\mathrm{p}<0.05)$ using the Statistica 7.0 software (Statsoft Inc., USA). Table 1 summarizes the tests used in this study.

\subsection{Antioxidant activity}

\section{$D P P H$ radical scavenging method}

Antioxidant activity was measured in terms of hydrogen donating or radical scavenging ability using the stable radical 2.2 diphenyl-1-picrylhydrazyl (DPPH), as described by Mensor et al. (2001).

The experiment consisted in the incubation of an ethanolic solution of DPPH, $0.3 \mathrm{mM}$, (Sigma - Aldrich, USA), for 30 minutes, added with essential oil at the concentrations of $5 ; 10 ; 25 ; 50 ; 125 ; 250 ; 500 \mu . \mathrm{mL}^{-1}$ in ethanol analytical grade (Merck S. A., Brazil), followed by an absorbance measurement at $517 \mathrm{~nm}$ using a FEMTO UV-Vis spectrophotometer (800XI - São Paulo, Brazil). The procedures were similar to those of the control sample, which consisted of the ethanolic DPPH solution without antioxidant. The blank sample contained solvent ethanol. The inhibition percentage of the sample tested on the DPPH radicals was estimated by Equation 1:

$A A \%=100-\frac{\left(A b s_{\text {sample }}-A b s_{\text {blank }}\right) \times 100}{A b s_{\text {control }}}$

where $A A \%$ is the percentage of antioxidant activity, $A b s$ is the absorbance of the sample, $A b s_{\text {control }}$ is the absorbance of the control sample, and $A b s_{\text {blank }}$ is the absorbance of the blank sample.

The concentration necessary to scavenge $50 \%$ of the free radical DPPH $\left(\mathrm{EC}_{50}\right)$ was estimated by linear regression.

\section{$\beta$-carotene bleaching method}

The method is based on measurements of $\beta$-carotene bleaching, which is generated by linoleic acid oxidation in an emulsion. The $\beta$-carotene loses the yellow color due to its reaction with radicals formed in this oxidation (MATTHÄUS, 2002; KANG et al., 2006). The rate of $\beta$-carotene bleaching was evaluated by the difference between the initial absorbance readings at $470 \mathrm{~nm}$ and after 120 minutes. The values of the percentage of antioxidant activity (AA \%) were estimated by

Table 1. Description of the tests performed for evaluation of antimicrobial activity of commercial turmeric (Curcuma longa) essential oil using the disk diffusion method.

\begin{tabular}{cl}
\hline Test & Description \\
\hline A & Commercial turmeric (Curcuma longa) essential oil against Listeria monocytogenes \\
B & Commercial turmeric (Curcuma longa) essential oil added with 0.8 mg.mL $\mathrm{m}^{-1}$ of ascorbic acid against Listeria monocytogenes \\
$\mathrm{C}$ & Commercial turmeric (Curcuma longa) essential oil added with $2.0 \mathrm{mg} \cdot \mathrm{mL}^{-1}$ of ascorbic acid against Listeria monocytogenes \\
$\mathrm{D}$ & Commercial turmeric (Curcuma longa) essential oil against Salmonella typhimurium \\
$\mathrm{E}$ & Commercial turmeric (Curcuma longa) essential oil added with $0.8 \mathrm{mg} \cdot \mathrm{mL}^{-1}$ of ascorbic acid against Salmonella typhimurium \\
$\mathrm{F}$ & Commercial turmeric (Curcuma longa) essential oil added with $2.0 \mathrm{mg} \cdot \mathrm{mL}^{-1}$ of ascorbic acid against Salmonella typhimurium
\end{tabular}


Equation 2. Absorbance analysis was measured using a FEMTO UV-Vis spectrophotometer (800XI - São Paulo, Brazil)

$$
A A \%=\left\{1-\left[\frac{A b s_{t, 120}-A b s_{t, 0}}{A b s_{\text {controlt }, 120}-A b s_{\text {controlt }, 0}}\right]\right\} \times 100
$$

where $A A \%$ is the percentage of antioxidant activity, $A b s_{t, 120}$ is the absorbance of the sample after 120 minutes, $A b s_{t, 0}$ is the absorbance of the sample at $t=0, A b s_{\text {controlt, } 120}$ is the absorbance of the control sample after 120 minutes, and $A b s_{\text {controlt, } 0}$ is the absorbance of the control sample at $t=0$.

\subsection{Analysis of the total content of the phenolic compounds}

The analysis of the total content of phenolic compounds was conducted by the Folin-Ciocalteu method (Sigma-Aldrich, USA - SINGLETON; ROSSI JUNIOR, 1965; PESCHEL et al., 2006) with standard curve of galic acid - GAE (Nuclear, CAQ Ind. e Com. Ltda., Brazil). In order to measure the absorbance, a FEMTO UV-Vis spectrophotometer (800XI - São Paulo, Brazil) at $765 \mathrm{~nm}$ was used. The results were expressed as milligrams of total phenolic compounds in galic acid per gram of turmeric essential oil (mg GAE.g ${ }^{-1}$ ).

\section{Results and discussion}

\subsection{Physicochemical analysis}

The specific weight value found was $0.8948 \mathrm{~g} \cdot \mathrm{mL}^{-1}$, and the refraction index of the commercial essential oil was 1.4917. Krishnamurthy et al. (1976) and Govindarajan and Stahl (1980) found close results for the specific weight of Indian Turmeric: 0.929 g. $\mathrm{mL}^{-1}$ at $20{ }^{\circ} \mathrm{C}$ and 0.9423 g.mL $\mathrm{mL}^{-1}$ at $24{ }^{\circ} \mathrm{C}$. In addition, similar results were obtained for the Brazilian Turmeric: 0.9068 g.mL $\mathrm{mL}^{-1}$ at $30{ }^{\circ} \mathrm{C}$ and 0.906 g. $\mathrm{mL}^{-1}$ at $25^{\circ} \mathrm{C}$ (PÉRET-ALMEIDA, 2006; NEGHETINI, 2006). The differences in these results may be attributed to differences in raw material, maturation of the samples, solvent used, and distillation time (GOVINDARAJAN; STAHL, 1980). The refraction index results found in the literature were 1.5069 at $25{ }^{\circ} \mathrm{C}$ (NEGHETINI, 2006), 1.5067 at $30{ }^{\circ} \mathrm{C}$ (PÉRET-ALMEIDA, 2006), and 1.5054 at $30^{\circ} \mathrm{C}$ (GOVINDARAJAN; STAHL, 1980).

\subsection{Antimicrobial activity}

\section{Method of disk diffusion}

The initial tests conducted with the pure commercial sample of the essential oil did not show antimicrobial activity against Listeria monocytogenes Scott A and Salmonella typhimurium ATCC.

However, after the addition of ascorbic acid, the resulting mixture showed antimicrobial activity against the two above mentioned microorganisms, as shown in Table 2 . The results agree with those obtained by Nanasombat and Lohasupthawee with ethanolic extract (2005), Franco et al. with essential oil (2007), and Fagbemi et al. (2009) with turmeric aqueous extract (Curcuma longa). Other studies showed that turmeric exhibits antimicrobial activity against fungi and non-pathogenic bacteria (NEGHETINI, 2006; NAZ et al., 2010).

It can be seen that this essential oil at concentrations ranging from 0.05 to $2.30 \mathrm{mg} \cdot \mathrm{mL}^{-1}$ added to ascorbic acid at concentrations of 0.8 and $2.0 \mathrm{mg} \cdot \mathrm{mL}^{-1}$ (tests $\mathrm{B}$ and C), exhibited inhibition zones between $9.0 \pm 1.0$ and $13.7 \pm 0.58 \mathrm{~mm}$ against Listeria monocytogenes. The maximum inhibition of both bacteria was obtained with $2.30 \mathrm{mg} \cdot \mathrm{mL}^{-1}$ of oil added to $2.0 \mathrm{mg} \cdot \mathrm{mL}^{-1}$ of ascorbic acid. The commercial oil added to $0.8 \mathrm{mg} \cdot \mathrm{mL}^{-1}$ of ascorbic acid presented antimicrobial activity only against Salmonella typhimurium at the concentration of $2.0 \mathrm{mg} \cdot \mathrm{mL}^{-1}$. This behavior can be attributed to the larger complexity of the double cell wall of Gram-negative bacteria,

Table 2. Antimicrobial activity of commercial turmeric (Curcuma longa) essential oil against pathogenic bacteria with filter paper disk of 6 mm.

\begin{tabular}{|c|c|c|c|c|c|c|}
\hline \multirow{2}{*}{ Concentration of oil (mg.mL $\left.\mathrm{mL}^{-1}\right)$} & \multicolumn{6}{|c|}{ Inhibition zone $(\mathrm{mm})^{(1)}$} \\
\hline & Test A & Test B & Test $\mathrm{C}$ & Test D & Test E & Test F \\
\hline 0.05 & nd & $9.0 \pm 1.0^{\mathrm{a}}$ & $9.3 \pm 0.6^{\mathrm{a}}$ & nd & nd & $10.2 \pm 1.0^{\mathrm{a}}$ \\
\hline 0.10 & nd & $9.0 \pm 1.0^{\mathrm{a}}$ & $9.7 \pm 0.6^{\mathrm{a}}$ & nd & nd & $10.7 \pm 0.6^{\mathrm{a}}$ \\
\hline 0.30 & nd & $9.0 \pm 1.0^{\mathrm{a}}$ & $9.7 \pm 0.6^{\mathrm{a}}$ & nd & nd & $11.2 \pm 0.8^{\mathrm{b}}$ \\
\hline 0.50 & nd & $9.0 \pm 1.7^{\mathrm{a}}$ & $10.0 \pm 0.0^{\mathrm{a}}$ & nd & nd & $11.8 \pm 0.3^{\mathrm{b}}$ \\
\hline 0.70 & nd & $9.7 \pm 0.6^{\mathrm{a}}$ & $11.2 \pm 0.3^{\mathrm{b}}$ & nd & nd & $12.2 \pm 1.0^{\mathrm{b}}$ \\
\hline 0.90 & nd & $10.0 \pm 0.0^{\mathrm{a}}$ & $12.4 \pm 0.5^{\mathrm{b}}$ & nd & nd & $12.2 \pm 1.0^{\mathrm{b}}$ \\
\hline 1.00 & nd & $10.0 \pm 1.0^{\mathrm{a}}$ & $12.6 \pm 0.8^{\mathrm{b}}$ & nd & nd & $12.7 \pm 0.3^{\mathrm{b}}$ \\
\hline 1.50 & nd & $10.0 \pm 0.0^{\mathrm{a}}$ & $12.6 \pm 0.8^{b}$ & nd & nd & $13.7 \pm 2.0^{\mathrm{b}}$ \\
\hline 2.00 & nd & $11.7 \pm 1.5^{\mathrm{ab}}$ & $13.5 \pm 1.3^{\mathrm{ab}}$ & nd & $11.3 \pm 1.5^{\mathrm{a}}$ & $14.8 \pm 1.8^{\mathrm{b}}$ \\
\hline 2.30 & nd & $12.5 \pm 0.7^{\mathrm{a}}$ & $13.7 \pm 0.6^{\mathrm{ab}}$ & nd & $12.7 \pm 0.6^{\mathrm{a}}$ & $15.0 \pm 1.4^{\mathrm{b}}$ \\
\hline Control sample & \multicolumn{3}{|c|}{ Listeria monocytogenes } & \multicolumn{3}{|c|}{ Salmonella typhimurium } \\
\hline Vit. C (0.8 mg.mL $\left.{ }^{-1}\right)$ & \multicolumn{3}{|c|}{$\mathrm{Nd}$} & \multicolumn{3}{|c|}{ nd } \\
\hline Vit. C (2.0 mg.mL $\left.\mathrm{mL}^{-1}\right)$ & \multicolumn{3}{|c|}{$10.2 \pm 1.1^{\mathrm{a}}$} & \multicolumn{3}{|c|}{$8.13 \pm 1.2^{\mathrm{a}}$} \\
\hline Ampicilin & \multicolumn{3}{|c|}{$18.3 \pm 1.7$} & \multicolumn{3}{|c|}{-} \\
\hline Amo/Clavulanic acid & \multicolumn{3}{|c|}{-} & \multicolumn{3}{|c|}{$20.7 \pm 0.6$} \\
\hline Gentamicin & \multicolumn{3}{|c|}{$22.0 \pm 0.0^{\mathrm{a}}$} & \multicolumn{3}{|c|}{$23.7 \pm 0.6^{\mathrm{b}}$} \\
\hline
\end{tabular}

\footnotetext{
${ }^{(1)}$ Lines and rows means with different letters differed significantly $(\mathrm{p}<0.05)$. nd $=$ not detected, $-=$ not tested.
} 
such as Salmonella typhimurium (HAMMER; CARSON; RILEY, 1999; CANSIAN et al., 2010).

Pure vitamin C control at $0.8 \mathrm{mg} \cdot \mathrm{mL}^{-1}$ did not prevent growth of both bacteria. On the other hand, the use of $2.0 \mathrm{mg} \cdot \mathrm{mL}^{-1}$ showed an inhibition zone of $10.2 \pm 1.08 \mathrm{~mm}$ for Listeria monocytogenes and of $8.13 \pm 1.21$ for Salmonella typhimurium. These results indicate a larger resistance of Salmonella typhimurium to the $\mathrm{pH}$ ranges used in this study. Therefore, it can be observed a synergism between the essential oil and the ascorbic acid.

Many studies showed that the synergism between ascorbic acid and phenolic compounds is due to the ascorbic acid ability to prevent the oxidation of the phenolic compounds. Since phenolic compounds are the main responsible for the antimicrobial activity of the turmeric oil, ascorbic acid favors this activity (NEGHETINI, 2006; HATANO et al., 2008; ZAMBUCHINI et al., 2008; NAZ et al., 2010). Studies on the interaction between turmeric essential oil and vitamin $\mathrm{C}$ were not found in the literature.

\subsection{Antioxidant activity}

\section{$D P P H$ radical scavenging method}

This test measures the hydrogen-atom- or electrondonating ability of the essential oil to convert DPPH into the form DPPH - H (diphenylpicrylhydrazyn) (CANSIAN et al., 2010). The experimental results were expressed as the reduction of the free radical DPPH by $50 \%$. The parameter $\mathrm{EC}_{50}$, which represents the inhibitory concentration necessary for this reduction, was used (QIAN; NIHORIMBERE, 2004; ARBOS et al., 2010).

The linear regression of the antioxidant activity (\%) and the oil concentration $\left(\mathrm{g} \cdot \mathrm{mL}^{-1}\right)\left(y=0.0227 x+2.462, R^{2}=0.862\right)$ provided a value of $2094.2 \mu \mathrm{g} \cdot \mathrm{mL}^{-1}$ to $\mathrm{EC}_{50}$, which has high magnitude when compared to reference standards such as $\mathrm{EC}_{50}=2.15 \mu \mathrm{g} \cdot \mathrm{mL}^{-1}$ for ascorbic acid and $\mathrm{EC}_{50}=5.37 \mu \mathrm{g} \cdot \mathrm{mL}^{-1}$ for BHT (CANSIAN et al., 2010). Table 3 presents some published results of $\mathrm{EC}_{50}$ obtained using the $\mathrm{DPPH}$ method for some species of plants and different solvents used to extract essential oils. Only a few studies containing data on antioxidant capacity of commercial essential oils are available in the literature. Benelli (2010) did not report finding antioxidant activity for commercial essential oil of orange for the concentration of $500 \mu \mathrm{g} . \mathrm{mL}^{-1}$. In the same study, turmeric commercial essential oil exhibited $14 \%$ of antioxidant activity.

\section{$\beta$-carotene bleaching method}

The antioxidant activity percentage (AA\%) found for curcuma essential oil using the $\beta$-carotene bleaching method was $29 \%$ for the concentration of $1.667 \mathrm{mg}$ of essential oil per $\mathrm{mL}$ of ethylic alcohol. The antioxidant activity obtained by linear regression for the concentration of $1.667 \mathrm{mg} \cdot \mathrm{mL}^{-1}$ using the DPPH radical scavenging method was about $40 \%$. The two methods furnished discordant results for the antioxidant activity, which can be attributed to the high solubility of flavonoids in polar solvents, such as the ethanol used to solubilize the radical DPPH. Aqueous and lipidic phases, which have low solubility, are used in this method instead of polar solvents (RICE-EVANS; NICHOLAS; PAGANGA, 1996; OLDONI, 2007).

Table 4 shows published results of antioxidant activity using for different species of plants using different extraction methods.

\subsection{Analysis of the total content of phenolic compounds}

The total content of phenolic compounds found was $56.79 \pm 1.37 \mathrm{mg}$ GAE.g ${ }^{-1}$. Chen et al. (2008) found $21.4 \pm 1.7 \mathrm{mg}$ GAE.g ${ }^{-1}$ for methanolic extract of Curcuma longa L., $33.4 \pm 5.7$ mg GAE.g ${ }^{-1}$ for Curcuma zedoaria, and $35.6 \pm 5.5 \mathrm{mg} \mathrm{GAE} . \mathrm{g}^{-1}$ for Curcuma domestica. Herrero et al.

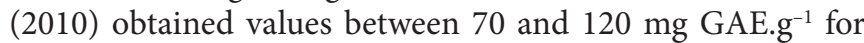
Rosemary extract using different solvents. This compound is often used as antioxidant in food formulations.

Commercial turmeric (Curcuma longa) essential oil was more effective considering its total content of phenolic compounds compared to the published results of methanolic extract, aqueous solution, and essential oil obtained in laboratory. In addition, the results obtained were close to those of the Rosemary essential oil.

Table 3. Effective concentration at $50 \%\left(\mathrm{EC}_{50}\right)$ for different species of plants and different solvents used to extract the essential oil obtained by the DPPH radical scavenging method.

\begin{tabular}{|c|c|c|c|c|}
\hline \multicolumn{2}{|r|}{ Species } & \multirow{2}{*}{ Extraction } & \multirow{2}{*}{$\mathrm{EC}_{50} \mu \mathrm{g} \cdot \mathrm{mL}^{-1}$} & \multirow{2}{*}{ Source } \\
\hline Common name & Scientific name & & & \\
\hline \multirow[t]{4}{*}{ Curcuma-selvagem } & Curcuma aromatica Salisb. & Essential oil (hydro-distillation) & 14.45 & Al-Reza et al. (2010) \\
\hline & & Extract (methanol) & 16.58 & \\
\hline & & Extract (cloroformium) & 38.86 & \\
\hline & & Extract (hexane) & 45.97 & \\
\hline Guaco & Mikania glomerata Spreng. & & 1283.88 & Vicentino and Menezes (2007) \\
\hline Ho-sho & Cinnamomum camphora Ness & Essential oil (hydro-distillation) & 12942.00 & Cansian et al. (2010) \\
\hline Oregano & Origanum dictamnus & Extract (petroleum ether) & 8385.00 & Kouri et al. (2007) \\
\hline Orange & Citrus sinensis L. Osbeck & $\begin{array}{l}\text { Commercial essential oil } \\
\text { (cold pressing) }\end{array}$ & nd & Benelli (2010) \\
\hline
\end{tabular}

$\mathrm{nd}=$ antioxidant activity not detected at concentrations up to $500 \mu \mathrm{g} \cdot \mathrm{mL}^{-1}$. 
Table 4. Results of the antioxidative activity (AA\%) obtained using the $\beta$-carotene bleaching method for different plant species and different extraction techniques.

\begin{tabular}{|c|c|c|c|c|c|}
\hline \multicolumn{2}{|r|}{ Species } & \multirow{2}{*}{ Extraction } & \multirow{2}{*}{$\begin{array}{l}\text { Concentration } \\
\left(\mathrm{mg} \cdot \mathrm{mL}^{-1}\right)\end{array}$} & \multirow{2}{*}{$\begin{array}{l}\mathrm{AA} \\
(\%)\end{array}$} & \multirow{2}{*}{ Source } \\
\hline Common name & Scientific name & & & & \\
\hline Turmeric & Curcuma longa & Essential oil (hydro-distillation) & 40.00 & 72.40 & Sacchetti et al. (2005) \\
\hline Rosemary & Rosmarinus officinalis & Essential oil (hydro-distillation) & 40.00 & 81.10 & \\
\hline Orange & Citrus sinensis L. Osbeck & $\begin{array}{l}\text { Commercial essential oil } \\
\text { (cold pressing) }\end{array}$ & 1.67 & 17.00 & Benelli (2010) \\
\hline \multirow[t]{2}{*}{ Alecrim-de-angola } & Vitex agnus castus $\mathrm{L}$. & $\begin{array}{l}\text { Essential oil } \\
\text { (hydro-distillation) }\end{array}$ & 2.00 & 86.17 & $\begin{array}{l}\text { Sarikurkcu et al. } \\
\text { (2009) }\end{array}$ \\
\hline & & Extract (methanol) & 2.00 & 53.14 & \\
\hline Oregano & Origanum vulgare $\mathrm{L}$. & Essential oil (hydro-distillation) & 2.00 & 64.00 & Kulisic et al. (2004) \\
\hline
\end{tabular}

\section{Conclusions}

The results of the specific weight and refraction index of commercial turmeric (Curcuma longa) essential oil indicate that it may contain some impurities due to extraction and handling processes.

Like the turmeric oils and extracts obtained in laboratory, the commercial essential oil did not exhibit antimicrobial activity against Listeria monocytogenes Scott A and Salmonella typhimurium ATCC. The addition of ascorbic acid to inhibit oxidation of phenolic compounds may be an alternative to increase the antimicrobial activity of the commercial turmeric essential oil. The results of antioxidant activity presented in this study were lower than the results published for both methods employed in this study. Further studies are necessary in order to obtain a better characterization of the antimicrobial and antioxidant properties of commercial Turmeric essential oil and its behavior when added with ascorbic acid.

\section{References}

AL-REZA, S. M. et al. Essential oil composition and antioxidant activities of Curcuma aromatica Salisb. Food and Chemical Toxicology, v. 48, p. 1757-1760, 2010. PMid:20385198. http://dx.doi. org/10.1016/j.fct.2010.04.008

ARBOS, K. A. et al. Atividade antioxidante e teor de fenólicos totais em hortaliças orgânicas e convencionais. Ciência e Tecnologia de Alimentos, v. 30, n. 2, p. 501-506, 2010. http://dx.doi.org/10.1590/ S0101-20612010000200031

BENELLI, P. Agregação de valor ao bagaço de laranja (Citrus sinensis L. Osbeck) mediante obtenção de extratos bioativos através de diferentes técnicas de extração. 2010. Dissertação (Mestrado em Engenharia de Alimentos)-Universidade Federal de Santa Catarina, Florianópolis, 2010.

BURKE, M. Curcumins dual defence against disease. Chemistry \& Industry, n. 8, p. 289, 1994. Complemento.

CANSIAN, R. L. et al. Atividade antimicrobiana e antioxidante do óleo essencial de ho-sho (Cinnamomum camphora Ness e Eberm Var. Linaloolifera fujita). Ciência e Tecnologia de Alimentos, v. 30, n. 2, p. 378-384, 2010. http://dx.doi.org/10.1590/S010120612010000200014
CHASSAGNEZ, A. L. M.; CORRÊA, N. C. F.; MEIRELES, M. A. A. Extração de oleoresina de cúrcuma (Curcuma longa) com CO2 supercrítico. Ciência e Tecnologia de Alimentos, v. 17, n. 4, 1997.

CHEN, I.-N. et al. Antioxidant and antimicrobial activity of zingiberaceae plants in Taiwan. Plant Foods and Human Nutrition, v. 63, p. 15-20, 2008. PMid:18157743. http://dx.doi.org/10.1007/ s11130-007-0063-7

FAGBEMI, J. F. et al. Evaluation of the antimicrobial properties of unripe banana (Musa sapientum L.), lemon grass (Cymbopogon citratus S.) and turmeric (Curcuma longa L.) on pathogens. African Journal of Biotechnology, v. 8, n. 7, p. 1176-1182, 2009.

FRANCO, A. L. P. et al. Avaliação da composição química e atividade antibacteriana dos óleos essenciais de aloysia gratissima (gillies \& hook) tronc. (alfazema), ocimum gratissimum L. (alfavaca-cravo) e curcuma longa. (açafrão). Revista Eletrônica de Farmácia, v. 4, n. 2, p. 208-220, 2007.

GOVINDARAJAN, V. S.; STAHL, W. H. Turmeric - chemistry, technology and quality. CRC Critical Reviews in Food Science and Nutrition, v. 12, n. 3, p. 199-301, 1980. PMid:6993103. http:// dx.doi.org/10.1080/10408398009527278

HAMMER, K. A.; CARSON, C. F.; RILEY, T. V. Antimicrobial activity of essential oils and other plant extracts. Journal of Applied Microbiology, v. 86, n. 6, p. 985-990, 1999. PMid:10438227. http:// dx.doi.org/10.1046/j.1365-2672.1999.00780.x

HATANO, T. et al. Enhancement of antibacterial effects of epigallocatechin gallate, using ascorbic acid. Phytochemistry, v. 69, p. 3111-3116, 2008. PMid:17889045. http://dx.doi.org/10.1016/j. phytochem.2007.08.013

HENTZ, S. M.; SANTIN, N. C. Avaliação da atividade antimicrobiana do óleo essencial de alecrim (Rosmarinus officinalis 1.) contra Salmonella sp. Evidência, v. 7, n. 2, p. 93-100, 2007.

HERRERO, M. et al. Green processes for the extraction of bioactives from Rosemary: Chemical and functional characterization via ultra-performance liquid chromatography-tandem mass spectrometry and in-vitro assays. Journal of Chromatography A, v. 1217 , p. 2512-2520, 2010. PMid:19945706. http://dx.doi. org/10.1016/j.chroma.2009.11.032

KANG, H. J. et al. Studies on the development of functional powder from citrus peel. Bioresource Technology, v. 97, p. 614-620, 2006. PMid:16153824. http://dx.doi.org/10.1016/j.biortech.2005.03.037

KOURI, G. et al. Extraction and analysis of antioxidant components from Origanum dictamnus. Innovative Food Science and Emerging 
Technologies, v. 8, p. 155-162, 2007. http://dx.doi.org/10.1016/j. ifset.2006.09.003

KRISHNAMURTHY, N. et al. Oil and oleoresin of turmeric. Tropical Science, v. 18, n. 1, p. 37-45, 1976.

KULISIC, T. et al. Use of different methods for testing antioxidative activity of oregano essential oil. Food Chemistry, v. 85, p. 633-640, 2004. http://dx.doi.org/10.1016/j.foodchem.2003.07.024

LEE, K. W. et al. Preventive effects of vitamin C on carcinogenesis. The Lancet, v. 359, p. 172, 2002. http://dx.doi.org/10.1016/S01406736(02)07358-0

MARINO, M.; BERSANI, C.; GIUSEPPE, C. Impedance measurements to study the antimicrobial activity of essential oils from Lamiaceae and Compositae. International Journal of Food Microbiology, v. 67 , p. 187-195, 2001. http://dx.doi.org/10.1016/S01681605(01)00447-0

MATTHÄUS, B. Antioxidant activity of extracts obtained from residues of different oilseeds. Journal of Agricultural and Food Chemistry, v. 50, p. 3444-3452, 2002. http://dx.doi.org/10.1021/jf011440s

MENSOR, L. L. et al. Screening of Brazilian plant extracts for antioxidant activity by the use of DPPH free radical method. Phytotherapy Research, v. 15, p. 127-130, 2001. PMid:11268111. http://dx.doi.org/10.1002/ptr.687

NANASOMBAT, S.; LOHASUPTHAWEE, P. Antibacterial activity of crude ethanolic extracts and essential oils of spices against salmonellae and other enterobacteria. KMITL Science and Technology Journal, v. 5, n. 3, 2005.

NAZ, S. et al. Antibacterial activity of Curcuma longa varieties against strains of bacteria. Pakistan Journal of Botany, v. 42, p. $455-462,2010$.

NEGHETINI, C. C. Caracterização físico-química e atividade antifúngica dos óleos essenciais da cúrcuma. 2006. Dissertação (Mestrado em Ciência de Alimentos)-Faculdade de Farmácia, Universidade Federal de Minas Gerais, Belo Horizonte, 2006.

NEGI, P. S. et al. Antibacterial activity of turmeric oil: a byproduct from curcumin manufacture. Journal of Agricultural and Food Chemistry, v. 47, p. 4297-4300, 1999. PMid:10552805. http://dx.doi. org/10.1021/jf990308d

OLDONI, T. L. C. Isolamento e identificação de compostos com atividade antioxidante de uma nova variedade de própolis brasileira produzida por abelhas da espécie Apis mellifera. 2007. Dissertação (Mestrado em Ciência e Tecnologia de Alimentos)Escola Superior de Agricultura Luiz de Queiroz, Universidade de São Paulo, Piracicaba, 2007.
PÉRET-ALMEIDA, L. Curcuma longa L. - Separação e caracterização de pigmentos curcuminóides, avaliação da atividade antimicrobiana, cultivo in vitro para o estabelecimento de gemas, calos, órgãos (raízes) e produção de metabólitos secundários. 2006. Tese (Doutorado em Ciência de Alimentos)-Faculdade de Farmácia, Universidade Federal de Minas Gerais, Belo Horizonte, 2006.

PESCHEL, W. et al. An industrial approach in the search of natural antioxidants from vegetable and fruit wastes. Food Chemistry, v. 97, p. 137-150, 2006. http://dx.doi.org/10.1016/j.foodchem.2005.03.033

QIAN, H.; NIHORIMBERE, V. Antioxidant power of phytochemicals from Psidium guajava leaf. Journal of Zhejiang University Science, v. 5, n. 6, p. 676-683, 2004. PMid:15101101. http://dx.doi. org/10.1631/jzus.2004.0676

RICE-EVANS, C. A.; NICHOLAS, J. M.; PAGANGA, G. Structure-antioxidant activity relationships of flavonoids and phenolic acids. Free Radical Biology and Medicine, v. 20, n. 7, p. 933-956, 1996. http://dx.doi.org/10.1016/0891-5849(95)02227-9

SACCHETTI, G. et al. Comparative evaluation of 11 essential oils of different origin as functional antioxidants, antiradicals and antimicrobials in foods. Food Chemistry, v. 91, p. 621-632, 2005. http://dx.doi.org/10.1016/j.foodchem.2004.06.031

SARIKURKCU, C. et al. Studies on the antioxidant activity of essential oil and different solvent extracts of Vitex agnus castus L. fruits from Turkey. Food and Chemical Toxicology, v. 47, p. 2479-2483, 2009. PMid:19595732. http://dx.doi.org/10.1016/j.fct.2009.07.005

SCARTEZZINI, P.; SPERONI, E. Review on some plants of indian traditional medicine with antioxidant. Journal of Ethnopharmacology, v. 17, p. 23-43, 2000. http://dx.doi. org/10.1016/S0378-8741(00)00213-0

SINGLETON, V. L.; ROSSI JUNIOR, J. A. Colorunetry of total phenolics with phosphomolybdic-phosphotungstic acid reagents. American Journal of Enology and Viticulture, v. 16, p. 144-158, 1965.

SOUZA, E. L. et al. Orégano (Origanum vulgare L., Lamiaceae): uma especiaria como potencial fonte de compostos antimicrobianos. Higiene Alimentar, v. 19, n. 132, p. 40-45, 2005.

VICENTINO, A. R. R.; MENEZES, F. S. Atividade antioxidante de tinturas vegetais, vendidas em farmácias com manipulação e indicadas para diversos tipos de doenças pela metodologia do DPPH. Revista Brasileira de Farmacognosia, v. 17, p. 384-387, 2007. http:// dx.doi.org/10.1590/S0102-695X2007000300014

ZAMBUCHINI, B. et al. Inhibition of microbiological activity during sole (Solea solea L.) chilled storage by applying ellagic and ascorbic acids. Lebensmittel-Wissenschaft und Technologie, v. 41, p. 1733-1738, 2008. http://dx.doi.org/10.1016/j.lwt.2007.11.004 